\title{
Identical Mutations in Unrelated Families with Generalized Resistance to Thyroid Hormone Occur in Cytosine-Guanine-rich Areas of the Thyroid Hormone Receptor Beta Gene
}

\author{
Analysis of 15 Families
}

\author{
Roy E. Weiss, * Michael Weinberg, * and Samuel Refetoff *\$ \\ ${ }^{*}$ Departments of Medicine and ${ }^{\ddagger}$ Pediatrics and the ${ }^{\S} \mathrm{J}$. P. Kennedy, Jr., Mental Retardation Research Center, \\ The University of Chicago, Chicago, Illinois 60637-1470
}

\begin{abstract}
Generalized resistance to thyroid hormone (GRTH) is a syndrome of variable reduction of tissue responsiveness to thyroid hormone. 28 different point mutations in the human thyroid hormone receptor beta (TR $\beta$ ) gene have been associated with GRTH. These mutations are clustered in two regions of the $T_{3}$ binding domain of the TR $\beta$ (codons 310-347 and 417-453). We now report point mutations in the TR $\beta$ gene of six additional families with GRTH and show that three mutations occurred each in three families with GRTH, and that three other mutations were each present in two families. In 11 of these 15 families, lack of a common ancestor could be confirmed by genetic analysis. 28 of the 38 point mutations so far identified, including all those occurring in more than one family, are located in cytosine-guanine-rich areas of the TR $\beta$ gene. Differences in clinical and laboratory findings in unrelated families harboring the same TR $\beta$ mutation suggest that genetic variability of other factors modulate the expression of thyroid hormone action. (J. Clin. Invest. 1993.91:2408-2415.) Key words: dinucleotide repeat polymorphism - allele specific amplification • thyrotropin • free thyroxine
\end{abstract}

\section{Introduction}

Generalized resistance to thyroid hormone (GRTH) ${ }^{1}$ is an inherited condition of reduced target tissue responsiveness to thyroid hormone characterized by a nonsuppressed thyrotropin (TSH) in spite of high concentrations of thyroid hormone (1). It has long been suspected that the condition is due to abnormalities at the level of the thyroid hormone receptor (TR) ( 2 , 3 ). The detection of two genes (TR $\alpha$ and $\operatorname{TR} \beta$ located on different chromosomes) that encode nuclear proteins, with identi-

This work was presented in part at the 74th Annual Meeting of the Endocrine Society, San Antonio, TX, 24-27 June 1992.

Address reprint requests to Roy E. Weiss, M.D., Ph.D., University of Chicago, MC3090, 5841 South Maryland Avenue, Chicago, IL 60637-1470.

Received for publication 3 August 1992 and in revised form 18 December 1992.

1. Abbreviations used in this paper: $\mathrm{FT}_{4}$, free thyroxine; $\mathrm{GRTH}$, generalized resistance to thyroid hormone; TR, thyroid hormone receptor; $\mathrm{TSH}$, thyrotropin; $\mathrm{TT}_{4}$, total thyroxine; $\mathrm{TT}_{3}$, total triiodothyronine.

J. Clin. Invest.

(c) The American Society for Clinical Investigation, Inc.

0021-9738/93/06/2408/08 \$2.00

Volume 91, June 1993, 2408-2415 cal thyroid hormone binding properties (4) led to the demonstration of linkage of the TR $\beta$ gene with GRTH (5). Subsequently, a single basepair substitution in the hormone binding domain of the TR $\beta$ was described in affected members of a family with GRTH (6). 28 point mutations have been since described in families with GRTH (6-22). With the exception of one mutation (16), all cluster in two regions in the triiodothyronine $\left(\mathrm{T}_{3}\right)$ binding domain of the TR $\beta$ (codons 310-347 and 417-453). Codons are numbered according to the corrected coding sequence of the $\operatorname{TR} \beta$ gene, which adds 5 amino acids to the amino terminus (23).

Each family with GRTH up until the present report was believed to have a unique mutation. Based on this latter finding, it was anticipated that differences in functional impairment of the mutant TRs would explain the variable manifestations of GRTH among families. Such relation has been demonstrated in vitro but not in vivo. Mammalian cells transfected with mutant TRs having lower binding affinity for $T_{3}$ required higher concentrations of the hormone to produce transactivation of a cotransfected thyroid hormone responsive reporter gene $(24,25)$. Surprisingly, this correlation was not found in vivo in terms of the severity of clinical manifestations. More specifically, subjects expressing the mutant $\operatorname{TR} \beta$ with fivefoldreduced $\mathrm{T}_{3}$-binding affinity had more severe impairment of mental function and growth than individuals from another family expressing a mutant TR with more than 100 -fold-reduced $\mathrm{T}_{3}$-binding affinity $(6,7,26)$. This discrepancy was present despite similar levels of endogenous thyroid hormone and the presence of unaltered expression of both mutant and normal TR $\beta$ genes in the heterozygous affected subjects (27).

Sequence analysis of the TR $\beta$ gene in more families with GRTH has led to the recognition of identical mutations in apparently unrelated families. We now report identical nucleotide substitution in the $\operatorname{TR} \beta$ gene occurring in affected members of different families with GRTH. Three of these mutations were each found in three families and three others, each in two families. In 11 of the 15 families, lack of a common ancestor was confirmed by genetic analysis. The mutations in six of the families have not been previously reported. All identical mutations occurred in $\operatorname{cytosine}(C)$-guanine $(G)$-rich regions of the $\operatorname{TR} \beta$ gene. Differences in clinical and laboratory findings in unrelated families harboring the same $\operatorname{TR} \beta$ mutation suggest that additional factors modulate the expression of the thyroid hormone resistance.

\section{Methods}

Reagents. Providers of biological reagents, including modifying and restriction enzymes, were Sigma Immunochemicals (St. Louis, MO), GIBCO BRL (Gaithersburg, MD), and New England BioLabs, Inc. 
(Beverly, MA). Sequenase version 2.0 DNA sequencing kits were purchased from U.S. Biochem. Corp. (Cleveland, OH). $\left[\alpha^{-}{ }^{35}\right.$ S $]$ dCTP was obtained from Amersham Corp. (Arlington Heights, IL). Synthetic oligonucleotides were synthesized by $\beta$-cyanoethyl chemistry using a DNA synthesizer (308B; Applied Biosystems, Inc., Foster City, CA ).

Subjects. 61 affected subjects belonging to 15 families are included in the study. Data from thyroid function tests and, when applicable, references to the first description of the families appear in Table I. All subjects had inappropriately normal TSH with elevated thyroid hormones, indicating reduced pituitary sensitivity to thyroid hormone. They had no symptoms or signs of thyrotoxicosis. The majority of subjects had goiters, and those tested failed to respond normally to the administration of supraphysiologic doses of $\mathrm{T}_{3}$ or $\mathrm{T}_{4}$.

DNA sequencing. DNA was isolated from peripheral blood leukocytes and/or from cultured skin fibroblasts (33). It was used for subsequent analyses and for TR $\beta$ gene sequencing of at least one affected member of each family. Exons 6, 7, and 8, comprising $75 \%$ of the $\mathrm{T}_{3}$-binding region of the TR $\beta$, were separately amplified using the PCR (35). For details on the structure of the $\operatorname{TR} \beta$ gene, see Takada et al. (34). The conditions of the reactions and the sequences of the oligonucleotides were those published by Usala et al. (36). The amplified DNA fragments were cloned into the M13 bacteriophage vector and sequenced by the dideoxynucleotide chain termination method (37) using Sequenase.

Confirmation of mutations. Several techniques were used to determine the presence or absence of each mutation in family members. Allele-specific amplification (6) was used to confirm the mutations in families F52 and F89. The identification of families ( F followed by a number) is according to the tabulation of all published families with GRTH (38). DNA from each individual was subjected to two PCRs, one with a pair of oligonucleotide primers, 5'-GGAGATCATGTCCCTTCGCG-3' ("normal primer") and 5'-AAAGCTCTTTGGATCCCCACTAACGAG-3' (primer $\alpha$ ) and the other with a pair of primers, one of which contained the mutant nucleotide (5'GGAGATCATGTCCCTTCGCA- -3 ', mutant nucleotide underlined).
Allele-specific amplification was not successful in confirming all mutations due to nonspecific amplification. Furthermore, not every mutation resulted in the creation or loss of a restriction endonuclease site. An alternative and novel approach to the confirmation of mutations was the synthesis of degenerate oligonucleotide primers complementary to sequences near the mutated nucleotide that produced a novel specific restriction site only if the DNA template contained the expected nucleotide substitution. Following amplification of the subjects' DNA by PCR, the DNA fragments were submitted to electrophoresis in acrylamide gel or in 3\% NuSieve/1\% agarose gel, before and after digestion with the specific enzyme. Partial cleavage of a DNA fragment indicated that the mutant nucleotide was present in one of the two alleles. A $20 \mathrm{mer}$ oligonucleotide primer was used for confirming the mutation in family F88 resulting in a new DrallI site (degenerated nucleotides are underlined ): 5'ATGTCCCTTCGCGCACTGT-3' and in families F29 and F106 resulting in a new Ncol site: 5'ATGGGGAAATGGCAGTGCCA-3'. The antisense oligonucleotide primer used in these reactions was the same (5'-AAAGCTCGGATCCCCACTAACGAG-3'). In family F95, however, the mutation itself resulted in a new restriction site (ApaLI), and the primers used were the same as for amplifying the exon for sequencing.

Confirmation of genetic unrelatedness by dinucleotide repeat polymorphism. The presence of dinucleotide (CA) repeat polymorphism in the TR $\beta$ intron flanked by exons 2 and $3(39)$ was used to determine whether members from different families harboring identical TR $\beta$ mutations had a common ancestor. A 197-209 bp fragment containing the region of variable lengths of CA repeats was amplified by PCR using oligonucleotide primers labeled at their $5^{\prime}$ end with ${ }^{35} \mathrm{P}$ by the kinase reaction. The resulting products were resolved on a polyacrylamide sequencing gel as described by Sakurai et al. (39).

Tests of thyroid function. Sera were available from individuals belonging to families F29, F45, F52, F88, F89, F95, and F106. Total thyroxine ( $\left.\mathrm{TT}_{4}\right)$ and triiodothyronine $\left(\mathrm{TT}_{3}\right)$ were measured by radioimmunoassays (Diagnostic Products Corp., Los Angeles, CA) and TSH by ELISA-2 (Nichols, San Juan Capastrano, CA). Free thyroxine

Table I. Hormonal Data and Family Identification*

\begin{tabular}{|c|c|c|c|c|c|c|c|c|}
\hline & $\begin{array}{l}\text { Family } \\
\text { ID }^{*}\end{array}$ & $\begin{array}{l}\mathrm{T}_{3} \text {-Affinity } \\
\text { of } \mathrm{TR} \beta^{s}\end{array}$ & $\mathrm{TT}_{4}$ & $\mathrm{TT}_{3}$ & TSH & $\mathrm{FT}_{4}$ & $N^{\prime \prime}$ & Reference \\
\hline & & & (nmol/liter) & (nmol/liter) & (mU/liter) & (\%) & & \\
\hline \multirow[t]{3}{*}{$M 1^{\prime}$} & F100 (E-D) $)^{* *}$ & 0.2 & 15 & 9.9 & 4.7 & - & $1(1)$ & 8 \\
\hline & F89 (XVIII) $)^{* *}$ & - & 360 & 3.1 & 4.2 & - & $1(1)$ & $9^{\ddagger \pm}$ \\
\hline & F52 (XIII) & - & $297 \pm 4$ & $5.3 \pm 0.0$ & $3.9 \pm 0.1$ & 292 & $2(2)$ & $28,29^{\ddagger \ddagger}$ \\
\hline \multirow[t]{2}{*}{ M2 } & F54 (WR) & $0.49 \pm 0.10$ & $196 \pm 29$ & $3.7 \pm 0.5$ & $3.2 \pm 1.4$ & $120 \pm 23$ & $13(14)$ & 18,30 \\
\hline & F88 (XIX) & - & $247 \pm 19$ & $3.3 \pm 0.7$ & $3.3 \pm 0.6$ & $182 \pm 31$ & $3(3)$ & $9,29^{\ddagger \ddagger}$ \\
\hline \multirow[t]{2}{*}{ M3 } & $\mathrm{F} 67(\mathrm{~K}-\mathrm{Cl})$ & $0.51 \pm 0.29$ & $192 \pm 24$ & $4.3 \pm 0.4$ & $2.2 \pm 1.3$ & $137 \pm 13$ & $6(7)$ & 12 \\
\hline & F95 (XVII) & - & $186 \pm 22$ & $3.2 \pm 0.4$ & $2.5 \pm 1.1$ & $118 \pm 29$ & $8(8)$ & $29^{\ddagger \pm}$ \\
\hline \multirow[t]{3}{*}{ M4 } & F29 (V) & - & $283 \pm 21$ & $5.2 \pm 1.2$ & $2.8 \pm 1.9$ & $213 \pm 19$ & $3(3)$ & $31^{\ddagger \pm}$ \\
\hline & F106 & - & $241 \pm 35$ & $4.3 \pm 0.8$ & $3.6 \pm 2.6$ & $200 \pm 13$ & $3(4)$ & $\$$ \\
\hline & F110(K-T) & 0.21 & 268 & 4.6 & 4.6 & 296 & $1(1)$ & 17 \\
\hline \multirow[t]{3}{*}{ M5 } & F45 (XII) & $0.14 \pm 0.21$ & $216 \pm 41$ & $5.1 \pm 1.1$ & $3.8 \pm 2.9$ & $216 \pm 80$ & $2(2)$ & 9,32 \\
\hline & F68 & - & - & - & $1.3 \pm 0.7$ & $181 \pm 16$ & $3(4)$ & 10 \\
\hline & F111 & 0.2 & & & & & $0(2)$ & 21 \\
\hline \multirow[t]{2}{*}{ M6 } & F85 & $0.46 \pm 0.02$ & $237 \pm 3$ & $3.9 \pm 0.2$ & $1.7 \pm 0.9$ & $183 \pm 39$ & $3(3)$ & 15 \\
\hline & F105 (Q-W) & 0.41 & 196 & 3.5 & 1.9 & 194 & $1(6)$ & 8 \\
\hline
\end{tabular}

* Data for $\mathrm{TT}_{4}, \mathrm{TT}_{3}$, and TSH are expressed as mean $\pm \mathrm{SD}$, and for $\mathrm{FT}_{4}$ as percent of the upper limit of normal. Except for F100 and F89, all values are from untreated patients.

₹ Family identification according to chronology of publication or presentation in our clinic. In parentheses is the ID used in the respective reference.

${ }^{8}$ Expressed as the ratio of the mutant-to-normal association constants of the TRs expressed in vitro.

"Number of affected subjects for whom hormonal data was available. Total number of affected individuals in each family are in parentheses.

'M1-M6 refer to the 6 different TR $\beta$ gene mutations in this report.

** Treated with T3 (F100) and T4 (F89) because of previous thyroid gland ablation. ${ }^{\ddagger}$ Subjects or mutations not previously published. 
(FT4) was estimated from the free $T_{4}$ index utilizing a resin $T_{4}$ uptake test (40). Results of affected subjects from each family were expressed as mean \pm SD. Published data from families F54, F67, F68, F85, F105, and F110 were used and normalized using the corresponding upper limits of normal. Statistical significance was determined by analysis of variance and by unpaired $t$ tests. $P$ values $\geq 0.05$ were considered not to be statistically significant.

\section{Results}

Six distinct mutations were found in 15 families, each present in at least two families (Table II). Seven of these families were studied in our laboratory, six of which have not been previously reported ( see Table I). In the latter families, the presence of a nucleotide substitution in the TR $\beta$ gene of all subjects affected by GRTH but not in normal relatives was confirmed. Allele-specific amplification was used to demonstrate the substitution of the normal G-1234 by an A (M1) in affected subjects of families F52 and F89. As shown in Fig. 1, this mutation was absent in the nonaffected natural parents of the 9-yr-old twin boys of family F52, indicating a de novo mutation. An identical mutation was found by sequencing and confirmed by the allele-specific amplification in a woman with GRTH (F89) who was $31 \mathrm{yr}$ old at the time of diagnosis. This patient was adopted and no other family members were available for testing.

The creation of a new ApaLI restriction site by the substitution of G-1244 by A (M3) was used to confirm the mutation in all affected members of family F95. An alternative approach, that of the loss of the recognition site for Hhal, was used by Cugini et al. (12) to identify the identical mutation in another family (F67). Confirmation that two other mutations were present only in subjects affected by GRTH necessitated the use of a degenerate oligonucleotide primer (see Methods), which together with the mutated nucleotide created a specific restriction site. This is illustrated in Fig. 2 for the detection of the substituted C-1243 for T (M2) in family F88, creating a new recognition site for DrallI. The same strategy was used to confirm the presence of specific nucleotide substitutions in the

Table II. Sites of Identical Mutations in HTR $\beta$ Gene of Families with GRTH

\begin{tabular}{clcccc}
\hline & & & \multicolumn{3}{c}{ Codon } \\
\cline { 5 - 6 } Mutation & Family ID & $\begin{array}{c}\text { Nucleotide } \\
\text { number }\end{array}$ & Number & Normal & Mutant \\
\hline M1 & F52 & 1234 & 317 & GCT (Ala) & ACT (Thr) \\
& F89 & & & & \\
M2 & F100 & & & & \\
& F54 & 1243 & 320 & CGC (Arg) & TGC (Cys) \\
M3 & F88 & & & & \\
& F67 & 1244 & 320 & CGC (Arg) & CAC (His) \\
M4 & F95 & & & & \\
& F196 & 1297 & 338 & CGG (Arg) & TGG (Trp) \\
& F110 & & & & \\
M5 & F45 & 1598 & 438 & CGC (Arg) & CAC (His) \\
& F68 & & & & \\
M6 & F111 & & & & F85 \\
& F105 & 1642 & 453 & CCT (Pro) & ACT (Thr) \\
\end{tabular}

A
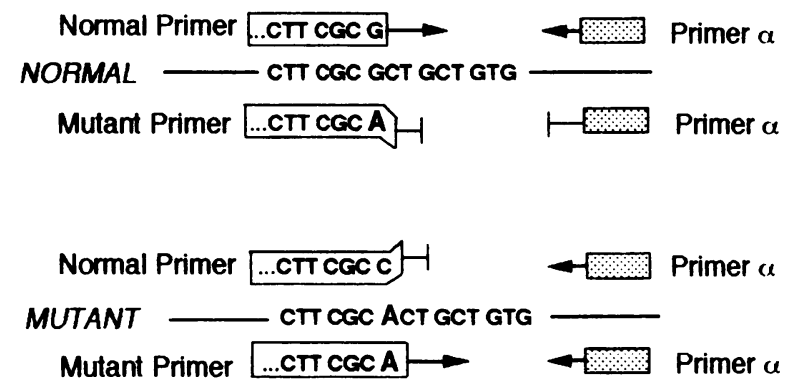

$\mathbf{B}$

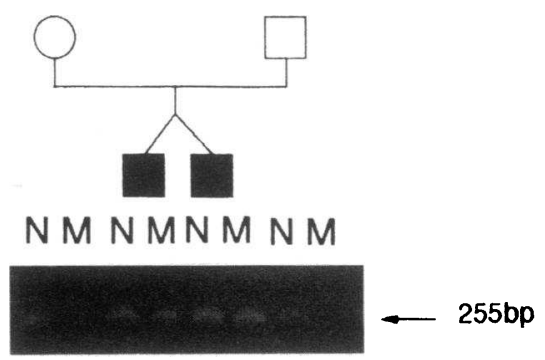

Figure 1. Allele-specific amplification confirming the replacement of G-1234 by an A in codon 317 of the TR $\beta$ gene in family F52. $(A)$ Oligonucleotide primers were complementary to the normal and mutant allele with the last nucleotide at the 3 ' end aligned with the mutated nucleotide. DNA from each individual was subjected to two PCR reactions, one with the normal primer and one with the mutant primer. Primer $\alpha$ was common for both reactions. A normal allele would only amplify with the normal primer and a mutant allele would only amplify with the mutant primer. (B) Pedigree of F52 showing that the affected twin boys (black symbols) had both a normal (N) and a mutant (M) allele confirming their heterozygous state. Both alleles of the unaffected parents (open symbols) were normal.

TR $\beta$ gene of families F29 and F106. In these two families with an identical mutation, C-1297 replaced by T (M4), DNA amplified with the degenerate oligonucleotide primer (see Methods) created a recognition site for Ncol only in the presence of the mutant nucleotide (data not shown).

Each of the six mutations under consideration (M1 through M6), their location on the TR $\beta$ gene, and the resulting amino acid replacement are shown in Table II. Mutations M1, M4, and M5 were each detected in three families (a total of nine families), while mutations M2, M3, and M6 were each found in two families (a total of six families). All mutations were clustered in two distinct areas of the $\mathrm{T}_{3}$-binding domain of the TR $\beta$, nucleotides $1214-1325$ and 1598-1661. It is of interest to note that all mutations occurring in more than one family involved guanines or cytosines substituted for adenines or thymidine.

Since it is possible for two presumably unrelated families to have a common ancestor, we undertook to demonstrate by genetic means that identical mutations in the TR $\beta$ gene occurred independently. Analysis of families harboring mutations M3 (F67 and F95) and M4 (F29 and F106) relied on CA repeat polymorphisms known to occur in the intron flanked by exons 2 and 3 of the TR $\beta$ gene (39). Results from such analysis of two families harboring an identical nucleotide substitution 

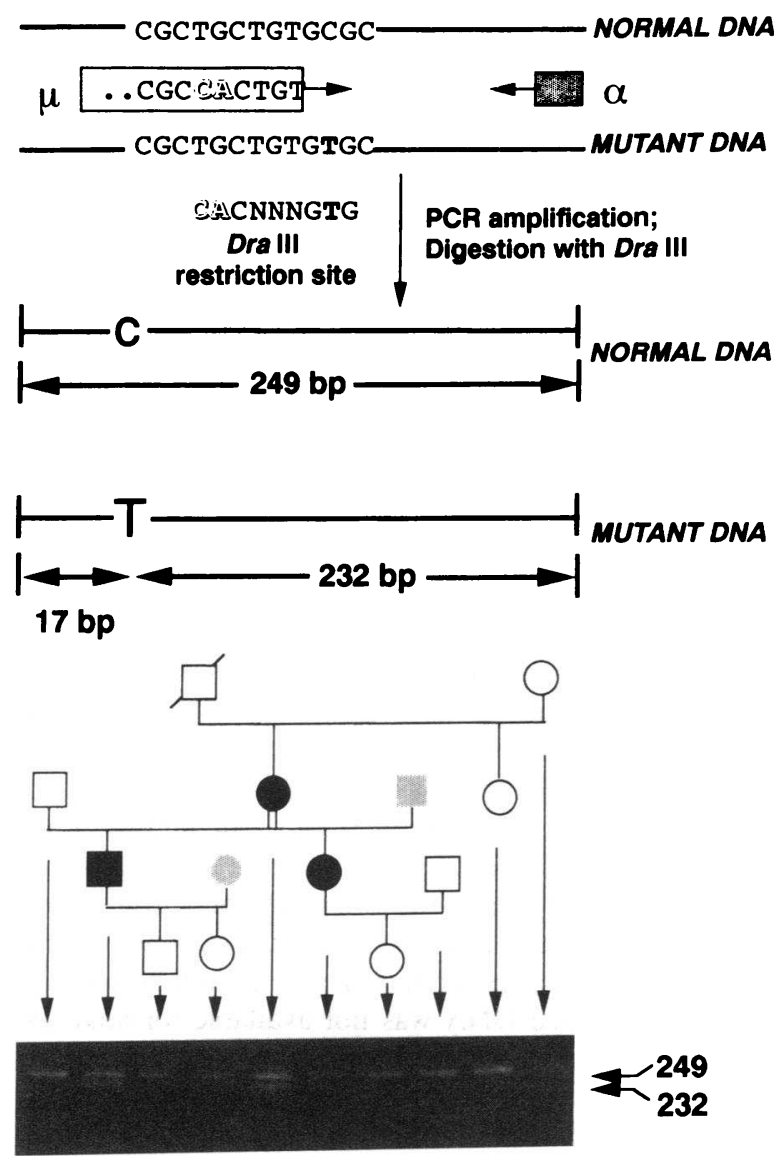

Figure 2. Creation of a restriction site for confirmation of the replacement of $\mathrm{C}-1243$ by a $\mathrm{T}$ in codon 320 of the TR $\beta$ gene in family F88. The mutation M2 in F88 did not create or delete a site for a restriction endonuclease. Therefore, a degenerate oligonucleotide primer $(\mu)$ was synthesized that would change the sequence of the PCR product such that a restriction site was formed only if the template DNA had the specific base substitution M2. Amplification using primer $\mu$ changed the TG in the patients' DNA to CA (outlined). The degenerate primer amplifies both normal and mutant alleles and does not overlap the mutation site. However, the presence of the mutant nucleotide, $T$, results in creation of a DrallI site. When the PCR product from each individual was subjected to DrallI digestion, a 249-bp ( uncut) fragment was visualized by $3 \%$ NuSieve/ $1 \%$ agarose electrophoresis in unaffected subjects (open symbols). The presence of a 249 bp (uncut) and 232 bp (cut) fragments in affected subjects (black symbols) confirmed the presence of a mutation in one of their two TR $\beta$ alleles. The 17-bp fragment was too small to be visualized.

in the coding region of the TR $\beta$ gene are illustrated in Fig. 3. The mutant M4 allele present in affected subjects of family F29 contained the polymorphic band 4, while the M4 allele of family F106 contained band 6 . These results confirm that the mutation M4 occurred independently in the two families. Furthermore, M4 was recently identified in an individual with GRTH (F110) in whom this mutation appeared de novo (17). Therefore, F110 is also unrelated to F29 and F106. DNA samples from family F67 (12), kindly provided by Dr. Stephen J. Usala, showed that the polymorphic band 7 was present in the allele containing mutation $\mathrm{M} 3$, while the identical mutation in family F95 had band 4 . We previously found a silent mutation ( T-1535 replaced by a C), preserving amino acid Phe-417, on the same allele and in the same exon as M5 in family F45 (9).
The allele harboring the M5 mutation in family F68 (10) maintained the wild type T-1535 (C. V. Boothroyd, personal communication ) confirming that mutation M5 in the two families also occurred independently. M5, recently detected in another family (F111), occurred de novo and was transmitted to a single affected child (21), indicating that this family with GRTH is not related to F45 and F68.

Evidence for the de novo occurrence of mutation M1 in families F52 and F100 is based on the observation that the parents of families F52 (Fig. 1) and F100 (8) were not affected. Since affected members of these families were $11 \mathrm{yr}$ old or younger and thus not in the reproductive age, the identical mutation found in the adopted subject of family F89 has occurred independently of the mutations in families F52 and F100. The criteria used to determine the genetic relatedness in all families with identical mutations in the $\mathrm{T}_{3}$-binding domain of the TR $\beta$ gene are shown in Table III.

Because clinical observations suggested that differences in the manifestations of GRTH existed not only among families with different mutations but also between families with the same mutation, we attempted to establish the presence of heterogeneity by more objective means. Since mean serum TSH levels were normal and not significantly different among the 10 families for whom sufficient data were available, we examined the corresponding mean serum $T_{4}$ and $T_{3}$ concentrations re-

F29

II

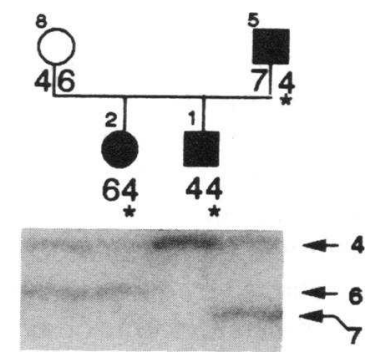

F 106
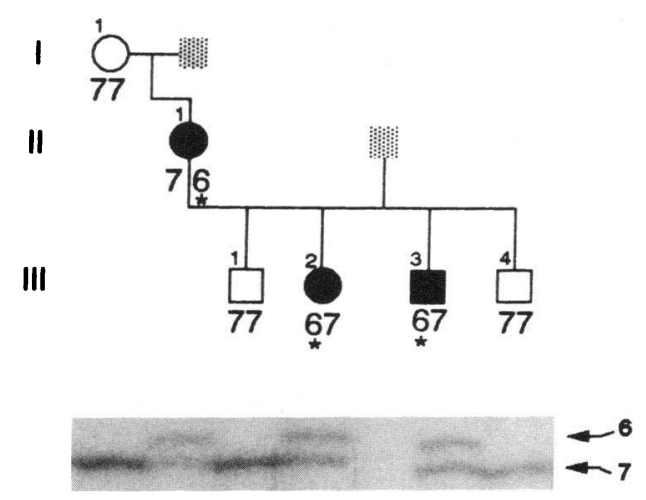

Figure 3. Determination of CA repeats polymorphism in the exclusion of founder's effect for the identical TR $\beta$ gene mutation (M4) in families F29 and F106. The black symbols represent affected individuals harboring the M4 mutation, the open symbols, unaffected individuals devoid of the M4 mutation, and the gray symbols, spouses that were not tested. Three different alleles were identified in F29, represented by bands 4,6 , and 7, and the 4 allele harbored the M4 mutation (asterisk). In contrast, the M4 mutation in family 106 was contained in the allele having the 6 CA-repeat pattern (asterisk). The roman numerals identify the generation and the number above each symbol the subject. 
Table III. Criteria Used to Determine Genetic Unrelatedness among Families with Identical TR $\beta$ Mutations

\begin{tabular}{|c|c|c|}
\hline Mutation & Family & Criteria \\
\hline \multirow[t]{2}{*}{ M1 } & $\begin{array}{l}\text { F52 and } \\
\text { F100 }\end{array}$ & $\begin{array}{l}\text { De novo mutations (both parents } \\
\text { unaffected) }\end{array}$ \\
\hline & F89 & Adopted \\
\hline \multirow[t]{2}{*}{$\mathbf{M} 2$} & F54* & Scottish descent, living in USA \\
\hline & F88 & $\begin{array}{l}\text { English/Irish/German/Amerindian } \\
\text { descent, living in USA }\end{array}$ \\
\hline \multirow[t]{2}{*}{ M3 } & F67 & Mutant allele had CA-repeats band "7" \\
\hline & F95 & Mutant allele had CA-repeats band " 4 " \\
\hline \multirow[t]{3}{*}{ M4 } & F29 & Mutant allele had CA-repeats band " 4 " \\
\hline & F106 & Mutant allele had CA-repeats band "6" \\
\hline & $\mathrm{F} 110^{*}$ & De novo mutation \\
\hline \multirow[t]{3}{*}{ M5 } & F45 & Silent substitution C-1535 (Phe-417) $)^{\ddagger}$ \\
\hline & F68 & Wild type T-1535 (Phe-417) \\
\hline & $\mathrm{F} 111^{*}$ & De novo mutation \\
\hline \multirow[t]{2}{*}{ M6 } & F85 & Japanese descent \\
\hline & F105 & Caucasian \\
\hline
\end{tabular}

* DNA not available.

‡ Same allele and exon as mutation M5.

quired to maintain comparable TSH levels. One pair of families (F54 and F88) with mutation M2 had significantly different mean $\mathrm{TT}_{4}$ values $(P<0.02)$, and another family pair ( F67 and F95) with mutation M3 showed significant difference ( $P$ $<0.02$ ) in their mean $\mathrm{TT}_{3}$ concentration (Table I). Free $\mathrm{T}_{4}$ level rather than $\mathrm{TT}_{4}, \mathrm{TT}_{3}$, or free $\mathrm{T}_{3}$ correlates best with the feedback regulation of TSH and is a measure of pituitary sensitivity to thyroid hormone $(41,42)$. We therefore compared the mean FT4 values among the families. Values were expressed as percent above the upper limit of normal in order to reduce the error in comparing data obtained by different laboratories. As shown in Fig. 4, significant differences were observed in free $\mathrm{T}_{4}$ levels between families with mutation M3 and those with M4 and M5. More surprisingly, a highly significant difference ( $P$ $<0.02$ ) in mean free $\mathrm{T}_{4}$ values was also found between families F54 and F88, both harboring the same M2 mutation.

\section{Discussion}

A previous search for mutations in the $\operatorname{TR} \beta$ gene identical to those found in two patients with GRTH indicated that mutations were probably unique to affected members of each unrelated family (29). Subsequent detection of $\operatorname{TR} \beta$ mutations in additional families with GRTH and in particular two studies

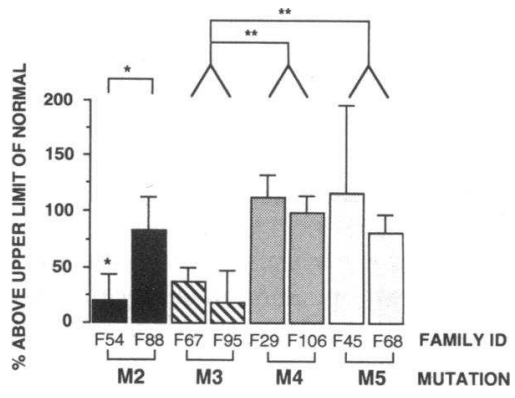

Figure 4. $\mathrm{FT}_{4}$ levels in families with GRTH. Results are expressed as mean percent above the upper limit of nor$\mathrm{mal} \pm \mathrm{SD} .{ }^{*} P=0.002$; ${ }^{* *} P<0.01$. No data was available for comparison of families with M1 and M6. each reporting seven and nine families, respectively $(8,9)$, also failed to show identical mutations in different families. We currently report six different mutations each present in 2 or 3 of 15 unrelated families. Obviously the need to confirm that the families with identical mutations have no common ancestor is not trivial. A physician may have sent patient material to more than one laboratory or the common ancestor may be distant and unknown to the families in question. Indeed, the mutation in the TR $\beta$ gene in one individual was reported by Parilla et al. ( 8 ) as case 1 of family F-W, and by us as subject VII-1 (9), independently. This subject with GRTH was first reported by Kaplowitz et al. (43) and then studied by us (29, 44, 45). After subsequent adoption, he moved to another state and came to the attention of Parilla et al. (8).

The criteria used to determine the genetic relation between families harboring identical mutations are listed in Table III. In 11 of the 15 families harboring four of the six mutations (M1, M3, M4, and M5), it was possible to confirm by direct gene analysis that the mutations occurred independently. In two families with M1 and one family each with M4 and M5 the mutations occurred de novo. In seven families (one with mutation M1 and two each with mutations M3, M4, and M5), although the lineage could not be traced back far enough to date the occurrence of their mutations, their independent development could be confirmed. The independent occurrence of mutation M2 and M6, each in two families, could not be assessed by genetic means since DNA was not available for analysis. Their different ethnic origins is suggestive but does not exclude a common ancestor.

37 of the 38 mutations so far reported, including the 6 described herein, cluster in the two regions of the $\mathrm{T}_{3}$-binding domain of the $\operatorname{TR} \beta$ previously identified $(8,9)$. Their nature and exact location in the TR $\beta$ gene are depicted in Fig. 5. 71\% of these mutations occur in 9 of the 16 CG-rich segments, with 4 or more Cs or Gs, located in a 448 bp segment of the TR $\beta$ coding sequence. Furthermore, of the six mutations found to occur independently in 15 unrelated families, five (M1, M2, M3, M4, and M5) were in regions of CG repeats and one (M6) in an area of $\mathrm{C}$ repeats. This is significant because such sequences are thought to be mutational hot spots in humans since they are frequent sites of polymorphisms (46). Regions with the dinucleotide CG in the Factor IX gene had a 77-fold increase in the mutation rate compared with the rates of other regions (47). In a review of single base-pair substitutions that cause human genetic diseases (excluding hemophilia), $32 \%$ of point mutations were CG to TG or CG to CA transitions (48). This represents a 12-fold higher frequency than that predicted to occur at random. The mechanism of this phenomenon appears to be methylation of cytosine 5 ' to guanine and the subsequent spontaneous deamination of 5-methylcytosine to thymine, which is not excised by the enzyme DNA-uracil glycosidase (49). GRTH, therefore, seems similar to other genetic diseases in humans in the frequency of this type of mutation, which was present in 14 of the 38 reported mutations (37\%) with 27 of $38(71 \%)$ occurring in CG-rich regions. Of the 34 point mutations recently described in the human androgen receptor (50-54), 15 were $\mathrm{T}$ and A transitions occurring in CGdinucleotides $(53 \%)$ but only $6(21 \%)$ occurred in CG-rich areas as defined above.

It is of interest that mutations have not been described between nucleotides 1326 and 1588 though this DNA segment 


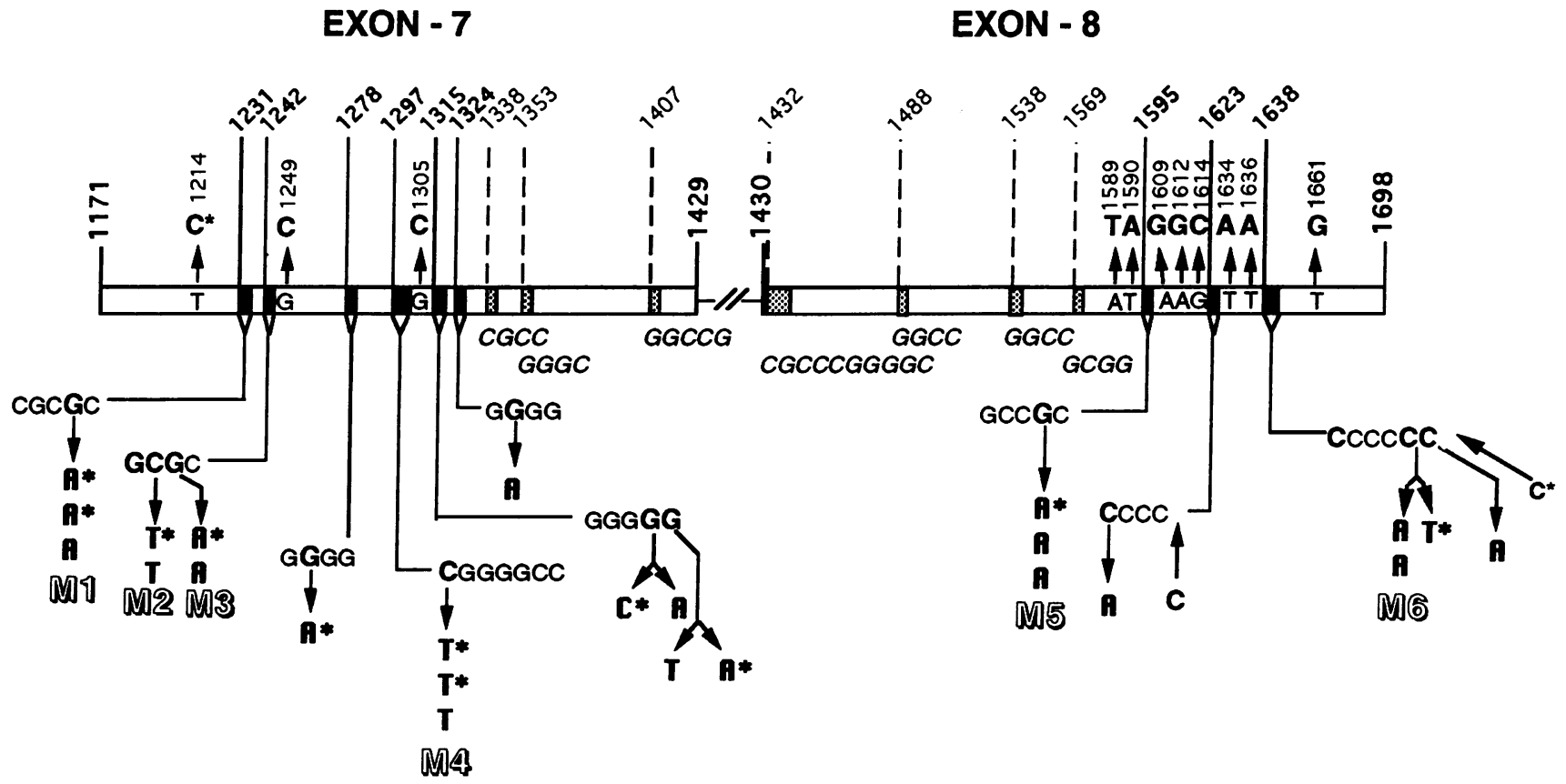

Figure 5. Summary of reported mutations in TR $\beta$ gene of subjects with GRTH. Mutations analyzed in this report are M1 through M6. *Mutations studied in our laboratory. CG-rich regions, defined as four or more adjacent Cs and Gs, are indicated in black and gray boxes. The black boxes are those areas where mutations have been identified, and the gray boxes are areas without known mutations. The first nucleotide of each CG repeat sequence is identified. The position of the mutated nucleotides outside the CG-rich areas are also indicated above.

contains CG rich sequences. This region of the TR $\beta$ gene encodes the heptad repeats forming a "leucine zipper" structure that is involved in receptor dimerization (55-57). Failure to detect individuals with mutations in this region can be explained by the inability of the mutant $\operatorname{TR} \beta$ to exert a "dominant negative effect" through formation of stable mutant TR $\beta$ homodimers (58), thus escaping clinical recognition. This hypothesis is consistent with the absence of clinical or laboratory abnormalities in heterozygous patients with complete deletion of the TR $\beta$ gene (34).

The recent observation that the degree of thyroid hormone resistance, as manifested by the clinical severity of GRTH, does not necessarily correlate with the degree of $\mathrm{T}_{3}$-binding impairment of mutant receptors $(26,27)$ is supported by the current data. In contrast to former studies, we had the opportunity to compare the free $\mathrm{T}_{4}$ levels required to maintain the same TSH value in four pairs of families, each with identical mutations of the TR $\beta$ gene. In one pair of families, F54 and F88, the mean free $\mathrm{T}_{4}$ concentration was significantly different at $P<0.02$ (Fig. 4). Although differences in other clinical characteristics, such as hyperactivity and bone maturation, were also observed between families with identical point mutations, they were difficult to quantify because of differences in subjects' ages. This is not to say that the degree of impairment of $\mathrm{T}_{3}$-binding does not contribute to the severity of the hormone resistance. It should be noted that the two families with mutation M3 had significantly lower free $T_{4}$ values than families with mutation M5, as well as three-fold higher affinity for $\mathrm{T}_{3}$ of their M3-mutant TR $\beta$ ( Table I, Fig. 5).

The possibility that the observed biochemical and clinical differences among families harboring identical mutations in the $\mathrm{T}_{3}$-binding domain of the TR $\beta$ may be due to a second mutation in the TR $\beta$ deserves serious consideration. Such mutations have not been detected in four families with GRTH in whom the entire coding region of the TR $\beta$ gene has been sequenced $(6,9,15,16)$ and in two families in whom sequencing comprised the $\mathrm{T}_{3}$-binding, DNA-binding, and hinge regions $(12,13)$. In addition, screening for mutations upstream of the $\mathrm{T}_{3}$-binding domain, including $75 \%$ of the DNA binding region, in six of the families described herein (F25, F45, F52, F88, F89, and F95) also failed to show an additional mutation (9). Furthermore, it can be speculated that functionally important mutations in the DNA-binding domain are less likely to have a significant biological effect in the heterozygous state since, as shown by site-directed mutagenesis (59), such mutations have no dominant negative effect. Thus, the most likely explanation for the apparent TR $\beta$ mutation independent differences in the degree of thyroid hormone resistance among families is the genetic variability of other factors that are involved in the expression of thyroid hormone action. Current evidence indicates that another thyroid hormone receptor ( $\operatorname{TR} \alpha$, located on chromosome 17), a number of transactivation protein cofactors ( RXR $\alpha$ and $\operatorname{RXR} \beta$ ), and less well-defined auxiliary TR proteins interact in the expression of thyroid hormone action $(56,60,61)$. The interaction results in the formation of stable complexes that bind to specific DNA sequences (thyroid hormone response elements) present in genes regulated by thyroid hormone. Undoubtedly, each of the involved factors and elements is subject to genetic polymorphism, which modulates its structure, interaction, and function. The genetically determined form and expression of a particular coregulator may diminish or augment the hormonal resistance imparted by a particular mutation in the TR $\beta$ gene and thus contribute to the modulation of the phenotype of GRTH. 


\section{Acknowledgments}

We thank the following individuals for the referral of patients or the provision of blood specimens: Dr. Gregory B. Pehling (F29), Dr. I. A. Hughes (F45), Dr. Barry H. Rich (F52), Dr. Corbin P. Roudebush (F88), Drs. Catherine M. Edwards and P. W. Stacpoole (F89), and Dr. Claudio Marcocci (F95). We are indebted to Dr. Stephen J. Usala for the provision of DNA samples from members of family F67, which served to determine their relatedness to F95, and to Drs. Graeme I. Bell, Yoshitaka Hayashi, Kenneth S. Polonsky, and Theodore Pullman for review of the manuscript. The assistance of Mrs. Yolanda W. Richmond in the preparation of the manuscript is also appreciated.

This work was supported in part by grants from the National Institutes of Health (DK-15070, DK-02081) and U.S. Public Health Service grant RR-00055.

\section{References}

1. Weiss, R. E., and S. Refetoff. 1992. Thyroid hormone resistance. Annu. Rev. Med. 43:363-375.

2. Weintraub, B. D., M. C. Gershengorn, I. A. Kourides, and H. Fein. 1981. Inappropriate secretion of thyroid stimulating hormone. Ann. Intern. Med. 95:339-351.

3. Refetoff, S. 1982. Syndromes of thyroid hormone resistance. Am. J. Physiol. 243:E88-E98.

4. Samuels, H. H., B. M. Forman, Z. D. Horowitz, and Y. Zheng-Sheng. 1988. Regulation of gene expression by thyroid hormone. J. Clin. Invest. 81:957-967.

5. Usala, S. J., A. E. Bale, N. Gesundheit, C. Weinberger, R. W. Lash, F. E Wondisford, O. W. McBride, and B. D. Weintraub. 1988. Tight linkage between the syndrome of generalized thyroid hormone resistance and the human c-erbA $\beta$ gene. Mol. Endocrinol. 2:1217-1220.

6. Sakurai, A., K. Takeda, K. Ain, P. Ceccarelli, A. Nakai, S. Seino, G. I. Bell, S. Refetoff, and L. J. DeGroot. 1989. Generalized resistance to thyroid hormone associated with a mutation in the ligand-binding domain of the human thyroid hormone receptor $\beta$. Proc. Natl. Acad. Sci. USA. 86:8977-8981.

7. Usala, S. J., G. E. Tennyson, A. E. Bale, R. W. Lash, N. Gesundheit, F. E. Wondisford, D. Accili, P. Hauser, and B. D. Weintraub. 1990. A base mutation of the c-erbA $\beta$ thyroid hormone receptor in a kindred with generalized thyroid hormone resistance. Molecular heterogeneity in two other kindreds. J. Clin. Invest. 85:93-100.

8. Parrilla, R., A. J. Mixson, J. A. McPherson, J. H. McClaskey, and B. D. Weintraub. 1991. Characterization of seven novel mutations of the c-erbA $\beta$ gene in unrelated kindreds with generalized thyroid hormone resistance. Evidence for two "hot spot" regions of the ligand binding domain. J. Clin. Invest. 88:21232130 .

9. Takeda, K., R. E. Weiss, and S. Refetoff. 1992. Rapid location of mutations in the thyroid hormone receptor $\beta$ gene by denaturing gradient electrophoresis in eighteen families with thyroid hormone resistance. J. Clin. Endocrinol. \& Metab. 74:712-719.

10. Boothroyd, C. V., B. T. The, N. K. Hayward, P. E. Hickman, G. J. Ward and D. P. Cameron. 1991. Single base mutation in the hormone binding domain of the thyroid hormone receptor $\beta$ gene in generalized thyroid hormone resistance demonstrated by single stranded conformation polymorphism analysis. Biochem. Biophys. Res. Commun. 178:606-612.

11. Usala, S. J., J. B. Menke, T. L. Watson, J. Bérard, W. E. C. Bradley, A. E. Bale, R. W. Lash, and B. D. Weintraub. 1991. A new point mutation in the 3,5,3'-triiodothyronine-binding domain of the c-erbA $\beta$ thyroid hormone receptor is tightly linked to generalized thyroid hormone resistance. J. Clin. Endo crinol. \& Metab. 72:32-38.

12. Cugini, C. D., Jr., J. W. Leidy, Jr., B. S. Chertow, J. Bérard, W. E. C. Bradley, J. B. Menke, E. H. Hao, and S. J. Usala. 1992. An arginine to histidine mutation in codon 315 of the c-erbA $\beta$ thyroid hormone receptor in a kindred with generalized resistance to thyroid hormones results in a receptor with significant 3,5,3'-triiodothyronine binding activity. J. Clin. Endocrinol. \& Metab 74:1164-1170.

13. Adams, M., T. Nagaya, Y. Tone, J. L. Jameson, and V. K. K. Chatterjee. 1992. Functional properties of a novel mutant thyroid hormone receptor in a family with generalized thyroid hormone resistance syndrome. Clin. Endocrinol. 36:281-289.

14. Saski, S., H. Nakamura, T. Tagami, Y. Miyoshi, K. Tanaka, and H. Imura. 1992. A point mutation of the $T_{3}$ receptor beta 1 gene in a kindred of generalized resistance to thyroid hormone. Mol. Cell Endocrinol. 84:159-166.

15. Shuto, Y., I. Wakabayashi, N. Amuro, S. Minami, and T. Okazaki. 1992 A point mutation in the 3,5,3'-triiodothyronine-binding domain of thyroid hormone receptor $\beta$ associated with a family with generalized resistance to thyroid hormone. J. Clin. Endocrinol. \& Metab. 75:213-217.
16. Behr, M., and U. Loos. 1992. A point mutation ( $\mathrm{Ala}^{229}$ to $\mathrm{Thr}$ ) in the hinge domain of the c-erbA $\beta$ thyroid hormone receptor in a family with generalized thyroid hormone resistance. Mol. Endocrinol. 6:1119-1126.

17. Mixson, A. J., R. Parrilla, S. C. Ransom, E. A. Wiggs, J. H. McClaskey, P. Hauser, and B. D. Weintraub. 1992. Correlations of language abnormalities with localization of mutations in the $\beta$-thyroid hormone receptor in 13 kindreds with generalized resistance to thyroid hormone: Identification of four new mutations. J. Clin. Endocrinol. \& Metab. 75:1039-1045.

18. Burman, K. D., Y. Y. Djuh, D. Nicholson, P. Rhooms, L. Wartofsky, H. G. Fein, S. J. Usala, E.-H. Hao, W. E. C. Bradley, J. Bérard, and R. C. Smallridge. 1992. Generalized thyroid hormone resistance: Identification of an arginine to cytosine mutation in codon 315 of the c-erbA beta thyroid hormone receptor. J. Endocrinol. Invest. 15:573-579.

19. Groenhout, E. G., and R. I. Dorin. 1992. Severe generalized thyroid hormone resistance due to a sporadic mutation in the c-erbA $\beta$ gene producing a truncated $T_{3}$ receptor protein. Annual Meeting of The Endocrine Society, San Antonio, TX June 24-27 (Abstr.). 135.

20. Tsukaguchi, Y., Y. Yoshimasa, K. Fujimoto, T. Yamamoto, S. Kato, H. Ishii, T. Yagura, S. Kashibara, J. Takamatsu, and N. Osawa. 1992. An analysis of the thyroid hormone receptor genes in patients with generalized thyroid hormone resistance. Thyroid 2 1(Suppl.):57. (Abstr.).

21. Gharib, H., T. Nagaya, J. L. Jameson, and N. L. Eberhardt. 1992. Characterization of a new thyroid hormone receptor mutant in generalized resistance to thyroid hormone. Thyroid 2 1(Suppl.):57. (Abstr.).

22. Pontecorvi, A., L. Bartolone, C. Regalbuto, D. Foti, S. Filetti, and M. Andreoli. 1992. Identification of a new missense mutation of thyroid hormone receptor $\beta$ gene in affected members of a family with generalized thyroid hormone resistance. Thyroid 2 1(Suppl.):28. (Abstr.).

23. Sakurai, A., A. Nakai, and L. J. DeGroot. 1990. Structural analysis of human thyroid hormone receptor $\beta$ gene. Mol. Cell Endocrinol. 71:83-91.

24. Meier, C. A., B. M. Dickstein, K. Ashizawa, J. H. McClaskey, P. Muchmore, S. C. Ransom, J. B. Menke, E. H. Hao, S. J. Usala, B. B. Bercu, S. Y. Cheng and B. D. Weintraub. 1992. Variable transcriptional activity and ligand binding of mutant $\beta 1$ 3,5,3'-triiodothyronine receptors from four families with generalized resistance to thyroid hormone. Mol. Endocrinol. 6:248-258.

25. Nagaya, T., L. D. Madison, and J. L. Jameson. 1992. Thyroid hormone receptor mutants that cause resistance to thyroid hormone. J. Biol. Chem 267:13014-13019.

26. Chatterjee, V. K. K., T. Nagaya, L. D. Madison, S. Datta, A. Rentoumis, and J. L. Jameson. 1991. Thyroid hormone resistance syndrome. Inhibition of normal receptor function by mutant thyroid hormone receptors. J. Clin. Invest. 87:1977-1984

27. Hayashi, Y., O. E. Janssen, R. E. Weiss, Y. Murata, H. Seo, and S. Refetoff. 1993. The relative expression of mutant and normal thyroid hormone receptor genes in patients with generalized resistance to thyroid hormone determined by estimation of their specific messenger ribonucleic products. J. Clin. Endocrinol. \& Metab. 76:64-69.

28. Sarne, D. H., S. Refetoff, R. L. Rosenfield, and J. P. Farriaux. 1988. Sex-hormone binding globulin in the diagnosis of peripheral tissue resistance to thyroid hormone: The value of changes following short-term triiodothyronine administration. J. Clin. Endocrinol. \& Metab. 66:740-746.

29. Takeda, K., S. Balzano, A. Sakurai, L. J. DeGroot, and S. Refetoff. 1991. Screening of nineteen unrelated families with generalized resistance to thyroid hormone for known point mutations in the thyroid hormone receptor $\beta$ gene and the detection of a new mutation. J. Clin. Invest. 87:496-502.

30. Smallridge, R. C., R. A. Parker, E. A. Wiggs, K. R. Rajagopal, and H. G. Fein. 1989. Thyroid hormone resistance in a large kindred: Physiologic, biochemical, pharmacologic, and neuropsychologic studies. Am. J. Med. 86:289-296.

31. Pagliara, A. S., R. H. Caplan, C. B. Gundersen, G. G. Wickus, and A. C. V. Elston III. 1983. Peripheral resistance to thyroid hormone in a family: Heterogeneity of clinical presentation. J. Pediatr. 103:228-232.

32. Hughes, I. A., K. Ichikawa, L. J. DeGroot, R. John, M. K. Jones, R. Hall, and M. F. Scanlon. 1987. Non-adenomatous inappropriate TSH hypersecretion and euthyroidism requires no treatment. Clin. Endocrinol. 27:475-483.

33. Bell, G. I., J. H. Karam, and W. J. Rutter. 1981. Polymorphic DNA region adjacent to the 5' end of the human insulin gene. Proc. Natl. Acad. Sci. USA. 78:5759-5763.

34. Takeda, K., A. Sakurai, L. J. DeGroot, and S. Refetoff. 1992. Recessive inheritance of thyroid hormone resistance caused by complete deletion of the protein-coding region of the thyroid hormone receptor- $\beta$ gene. J. Clin. Endocrinol. \& Metab. 74:49-55.

35. Saiki, R. K., D. H. Gelfand, S. Stoffel, S. J. Scharf, R. Higuchi, G. T. Horn, K. B. Mullis, and H. A. Erlich. 1988. Primer-directed enzymatic amplification of DNA with thermostable DNA polymerase. Science (Wash. DC). 239:487-494.

36. Usala, S. J., J. B. Menke, T. L. Watson, F. E. Wondisford, B. D. Weintraub, J. Bérard, W. E. C. Bradley, S. Ono, O. T. Mueller, and B. B. Bercu. 1991. A homozygous deletion in the c-erbA $\beta$ thyroid hormone receptor gene in a patient with generalized thyroid hormone resistance: isolation and characterization of the mutant receptor. Mol. Endocrinol. 5:327-335. 
37. Sanger, F., S. Nicklen, and A. R. Coulson. 1977. DNA sequencing with chain terminating inhibitors. Proc. Natl. Acad. Sci. USA. 74:5463-5467.

38. Refetoff, S., R. E. Weiss, and S. J. Usala. 1993. The syndromes of resistance to thyroid hormone. Endocr. Rev. In press.

39. Sakurai, A., G. I. Bell, and L. J. DeGroot. 1992. Dinucleotide repeat polymorphism in the human thyroid receptor $\beta$ gene (THR $\beta$ ) on chromosome 3 Nucleic Acids Res. 19:6661.

40. Robin, N. I., S. R. Hagen, F. Collaço, S. Refetoff, and H. A. Selenkow. 1971. Serum tests for measurement of thyroid function. Hormones (Basel) 2:266-279.

41. Leiblich, J., and R. D. Utiger. 1972. Triiodothyronine radioimmunoassay. J. Clin. Invest. 51:157-166.

42. Larsen, P. R. 1972. Triiodothyronine review of recent studies of its physiology and pathophysiology in man. Metab. Clin. Exp. 21:1073-1092.

43. Kaplowitz, P. B., A. J. D'Ercole, and R. D. Utiger. 1981. Peripheral resistance to thyroid hormone in an infant. J. Clin. Endocrinol. \& Metab. 53:958963.

44. Murata, Y., S. Refetoff, A. L. Horwitz, and T. J. Smith. 1983. Hormonal regulation of glycosaminoglycan accumulation in fibroblasts from patients with resistance to thyroid hormone. J. Clin. Endocrinol. \& Metab. 57:1233-1239.

45. Ceccarelli, P., S. Refetoff, and Y. Murata. 1987. Resistance to thyroid hormone diagnosed by the reduced response of fibroblasts to the triiodothyronine induced suppression of fibronectin synthesis. J. Clin. Endocrinol. \& Metab. 65:242-246.

46. Barker, D., M. Schafer, and R. White. 1984. Restriction sites containing CpG show a higher frequency of polymorphism in human DNA. Cell. 36:131138 .

47. Koeberl, D. D., C. D. K. Bottema, J.-M. Buerstedde, and S. S. Sommer. 1989. Functionally important regions of the factor IX gene have a low rate of polymorphism and a high rate of mutation in the dinucleotide CpG. Am. J. Hum. Genet. 45:448-457.

48. Cooper, D. N., and M. Krawczak. 1990. The mutational spectrum of single base-pair substitutions causing human genetic disease: Patterns and predictions. Hum. Genet. 85:55-74.

49. Coulondre, C., J. H. Miller, P. J. Farabaugh, and W. Gilbert. 1978. Molecular basis of base substitution hotspots in Escherichia coli. Nature (Lond.). 274:776-780.

50. Brown, T. R., D. B. Lubahn, E. M. Wilson, F. S. French, C. J. Migeon, and J. L. Corden. 1990. Functional characterization of naturally occurring mutant androgen receptors from subjects with complete androgen insensitivity. $\mathrm{Mol}$. Endocrinol. 4:1759-1772.

51. Ris-Stalpers, C., M. A. Trifiro, G. G. J. M. Kuiper, G. Jenster, G. Romalo, T. Sai, H. C. J. van Rooij, M. Kaufman, R. L. Rosenfield, S. Liao, H. U. Schwei- kert, J. Trapman, L. Pinsky, and A. O. Brinkmann. 1991. Substitution of aspartic acid- 686 by histidine or asparagine in the human androgen receptor leads to a functionally inactive protein with altered hormone-binding characteristics. Mol. Endocrinol. 5:1562-1569.

52. Nakao, R., M. Haji, T. Yanase, A. Ogo, R. Takayanagi, T. Katsube, Y. Fukumaki, and H. Nawata. 1992. A single amino acid substitution (Met ${ }^{786} \rightarrow$ $\mathrm{Val}$ ) in the steroid-binding domain of human androgen receptor leads to complete androgen insensitivity syndrome. J. Clin. Endocrinol. \& Metab. 74:11521157.

53. McPhaul, M. J., M. Marcelli, S. Zoppi, C. M. Wilson, J. E. Griffin, and J. D. Wilson. 1992. Mutations in the ligand-binding domain of the androgen receptor gene cluster in two regions of the gene. J. Clin. Invest. 90:2097-2101.

54. DeBellis, A., C. A. Quigley, N. F. Cariello, M. K. El-Awady, M. Sar, M. V. Lane, E. M. Wilson, and F. S. French. 1992. Single base mutations in the human androgen receptor gene causing complete androgen insensitivity: Rapid detection by a modified denaturing gradient gel electrophoresis technique. Mol. Endocrinol. 6:1909-1920.

55. Forman, B. M., C. R. Yang, M. Au, J. Casanova, J. Ghysdael, and H. H. Samuels. 1989. A domain containing leucine-zipper-like motifs mediate novel in vivo interactions between the thyroid hormone and retinoic acid receptors. $\mathrm{Mol}$. Endocrinol. 3:1610-1626.

56. Darling, D. S., J. S. Beebe, J. Burnside, E. R. Winslow, and W. W. Chin 1991. 3,5,3'-triiodothyronine $\left(T_{3}\right)$ receptor-auxiliary protein (TRAP) binds DNA and forms heterodimers with the $T_{3}$ receptor. Mol. Endocrinol. 5:73-84.

57. Spanjaard, R. A., D. S. Darling, and W. W. Chin. 1991. Ligand-binding and heterodimerization activities of a conserved region in the ligand-binding domain of the thyroid hormone receptor. Proc. Natl. Acad. Sci. USA. 88:85878591.

58. Yen, P. M., A. Sugawara, S. Refetoff, and W. W. Chin. 1992. New insights on the mechanism(s) of the dominant negative effect of mutant thyroid hormone receptor in generalized resistance to thyroid hormone. J. Clin. Invest. 90:18251831 .

59. Nagaya, T., L. D. Madison, and J. L. Jameson. 1992. Thyroid hormone receptor mutants that cause resistance to thyroid hormone. Evidence for receptor competition for DNA sequences in target genes. J. Biol. Chem. 267:1301413019.

60. Yu, V. C., C. Delsert, B. Andersen, J. M. Holloway, O. V. Devary, A. M. Näär, S. Y. Kim, J.-M. Boutin, C. K. Glass, and M. G. Rosenfeld. 1991. RXRß: a coregulator that enhances binding of retinoic acid, thyroid hormone, and vitamin $D$ receptors to their cognate response elements. Cell. 67:1251-1266.

61. Zhang, X.-K., B. Hoffmann, P. B. V. Tran, G. Graupner, and M. Pfahl. 1992. Retinoid $X$ receptor is an auxiliary protein for thyroid hormone and retinoic acid receptors. Nature (Lond.). 355:441-446. 